\title{
COMPARATIVE STUDY OF THE PROTECTIVE EFFECT OF N-ACYTEL CYSTEINE AND MELATONIN ON METHOTREXATE INDUCED RENAL TOXICITY IN MALES ALBINO RATS
}

\author{
Hala Said , Amany Salah ${ }^{*}$, AlaaShehab ${ }^{*}$, Ahmed Elshatory ${ }^{*}$, Omayma Elkholy ${ }^{* *}$,
} Gorge Nazih $^{* *}$ and Walaa Awad

*Forensic Medicine and Clinical Toxicology department, ${ }^{* *}$ Biochemistry department, Faculty of Medicine, Cairo University and ${ }^{* * *}$ Egyptian Fellowship of Clinical Pharmacy.

\begin{abstract}
Background: Methotrexate (MTX) is widely used as a cytotoxic chemotherapeutic agent for malignancies as well as in the treatment of various inflammatory diseases. MTX treatment has been associated with renal toxicity. The current study was conducted to assess the potential protective role of $\mathrm{N}$-acetylcysteine and/or melatonin in attenuation of methotrexate-induced renal damage in MTX intoxicated male albino rats.

Methods: sixty, apparently healthy adult male albino rats weighed $150 \pm 10 \mathrm{gm}$ were randomly divided into six groups; (group 1: negative control group, group 2: positive control (NAC treated) group, group 3: positive control (Melatonin treated) group, group 4: MTX treated group, group 5: MTX/NAC treated group, group 6: MTX/Melatonin treated group). The rats were treated once daily for 12 weeks by I.V injection of Methotrexate in a dose of $2 \mathrm{mg} / \mathrm{kg}\left(1 / 7 \mathrm{LD}_{50}\right), \mathrm{N}$-acetylcysteine in a dose of $80 \mathrm{mg} / \mathrm{kg}\left(1 /{ }_{14} \mathrm{LD}_{50}\right)$ and Melatonin: in a daily dose of $10 \mathrm{mg} / \mathrm{kg}\left(1 / 36 \mathrm{LD}_{50}\right)$ in the tail veins of rats and blood samples were obtained at the end of the $4^{\text {th }}, 8^{\text {th }}$ and $12^{\text {th }}$ weeks and were prepared for Creatinine examination. At the end of the study, kidney samples were obtained for histopathological examination.

Results: A significant constant increase in the creatinine of the MTX-treated group (group 4) was observed throughout the study. Supplementation of NAC concomitantly with MTX in group 5 reduced significantly creatinine when compared to the non-supplemented group 4 that treated with MTX at the $4^{\text {th }}, 8^{\text {th }}$ and $12^{\text {th }}$ weeks. On the other hand, the use of the melatonin in combination with MTX in group 6 produced minimal non-significant reduction of the creatinine level relative to group 4 at the $4^{\text {th }}, 8^{\text {th }}$ and $12^{\text {th }}$ weeks $(\mathrm{P}>0.05)$. The previous chemical results were confirmed by the histopathological studies of the kidney that revealed maximal affection of the renal cortex in the MTX-treated rats (group 4). Kidney histopathologic findings were significantly milder when NAC was co-administered with MTX in groups 5. Meanwhile, deterioration of the renal cortical structure was observed in the MTX melatonin treated rats (group 6).

Conclusion: The present study showed that NAC has a superior protective effect than Melatonin against the renal damage induced by MTX in male albino rats.

\section{INTRODUCTION}

Methotrexate's primary route of elimination is renal. Patients with a potential for impaired renal function

(e.g. those taking nephrotoxic drugs) are at increased risk of developing methotrexate toxicity. Precipitation of methotrexate or its relatively insoluble
\end{abstract}


metabolites in the renal tubules can cause acute renal failure and tubular necrosis (Buchen et al., 2005).

High-dose methotrexate (HDMTX, $>1 \mathrm{~g} / \mathrm{m}^{2}$ ) administered as an intravenous (i.v.) infusion is an important component in the treatment regimens for a variety of cancers (Widemann BC et al., 2004).

HDMTX-associated severe acute renal failure (ARF) is an infrequent but serious complication because MTX is predominantly excreted in the urine. Data from a number of studies performed in the 1970s showed that a sustained elevation of serum MTX concentrations at $24 \mathrm{~h}(\geq 5 \mu \mathrm{mol} / \mathrm{L}), 48$ $\mathrm{h}(\geq 1 \mu \mathrm{mo} / \mathrm{L})$ and $72 \mathrm{~h}(\geq 0.1 \mu \mathrm{mo} / \mathrm{L})$ after the start of the MTX infusion is considered to be toxic. The usual serum MTX level $48 \mathrm{~h}$ after HDMTX is $<0.1$ $\mu \mathrm{mol} / \mathrm{L}$

(Widemann BC, Adamson PC 2006).

Many drugs have been tested with the aim of preventing radiocontrastinduced nephropathy, and in 2000, NAC was discovered for this purpose (Tepel and Zidek 2004).

NAC has, however, rapidly become widely used for kidney protection (Pannu et al., 2004). Several metaanalyses have also been published; some concluded that NAC, when added to conventional hydration, decreases the risk of radiocontrast nephropathy in patients with chronic renal failure (Duong et al., 2005).

Koch et al. have described a direct association between a decrease in renal function and a decrease in melatonin production (Koch et al., 2009). The strong anti-oxidative properties of melatonin might be used to lower the risk of deterioration of kidney function. Melatonin exerts its anti-oxidative properties directly by scavenging free radicals, such as reactive oxygen species (ROS (Rodriguez et al., 2004).

\section{METHODS}

Chemicals used:

1. Methotrexate: It is manufactured by Pfizer Australia Pty Ltd. It was given intravenously in tail veins of rats in a daily dose of $2 \mathrm{mg} / \mathrm{kg}(1 / 7$ $\mathrm{LD}_{50}$ ).

2. N-acetylcysteine: It is manufactured by American International Chemical, Inc. It was given intravenously in tail veins of rats in a daily dose of $80 \mathrm{mg} / \mathrm{kg}\left({ }_{1}^{1} / \mathrm{LD}_{50}\right)$.

3. Melatonin: It is manufactured by Taj Pharmaceuticals Limited. It was given intravenously in tail veins of rats in a daily dose of $10 \mathrm{mg} / \mathrm{kg}\left({ }^{1} / 36\right.$ $\mathrm{LD}_{50}$ ).

Animals used \& Experimental Design:

Sixty, apparently healthy, adult male albino rats $(150 \pm 10$ gm body weight) were obtained from Animal house of Faculty of Medicine-Cairo University. They were housed in hygienic metal cages and kept in a clean well ventilated room. They were fed on standard laboratory diet and allowed free access to water. Rats were left for two weeks before commencement of the study to be acclimatized to lab conditions. All rats were weighed weekly in order to adjust the dose of drugs according to body weight. All doses were given once daily for 12 weeks. Blood samples were obtained at the end of the $4^{\text {th }}$, $8^{\text {th }}$ and $12^{\text {th }}$ weeks and were prepared for creatinine examination. By the end of the study; animals' samples were obtained for kidney histopathological examination.

Animals were randomly classified into 6 groups:

Group1 (negative control): 10 rats were injected I.V. with $1 \mathrm{ml}$ 
distilled water once daily for 12 weeks.

Group2 (Positive control):10 rats were supplemented with Nacetylcysteine in dose of $80 \mathrm{mg} / \mathrm{kg}$ body weight $\left(\begin{array}{lll}1 / 14 & \left.\mathrm{LD}_{50}\right) & \text { by }\end{array}\right.$ intravenous route daily for 12 weeks.

Group3 (positive control):10 rats were supplemented with melatonin in dose of $10 \mathrm{mg} / \mathrm{kg}$ body weight $(1 / 36$ $\mathrm{LD}_{50}$ ) by intravenous route daily for 12 weeks.

Group 4: 10 rats were supplemented with methotrexate in dose of 2 $\mathrm{mg} / \mathrm{kg}$ body weight $\left(1 / 7 \mathrm{LD}_{50}\right)$ by intravenous route daily for 12 weeks.

Group 5: 10 rats were supplemented with methotrexate in dose of 2 $\mathrm{mg} / \mathrm{kg}$ body weight $\left(1 / 7 \mathrm{LD}_{50}\right)$ and $\mathrm{N}$-acetylcysteine in dose of 80 $\mathrm{mg} / \mathrm{kg}$ body weight $\left(1 / 14 \mathrm{LD}_{50}\right)$ by intravenous route daily for 12 weeks.

Group6: 20 rats were supplemented with methotrexate in dose of 2 $\mathrm{mg} / \mathrm{kg}$ body weight $\left(1 / 7 \mathrm{LD}_{50}\right)$ and melatonin in dose of $10 \mathrm{mg} / \mathrm{kg}$ body weight $\left(\begin{array}{ll}1 / 36 & \left.\mathrm{LD}_{50}\right) \\ \text { by }\end{array}\right.$ intravenous route daily for 12 weeks.

\section{Biochemical Studies:}

Blood samples were obtained at the end of the $4^{\text {th }}, 8^{\text {th }}$ and $12^{\text {th }}$ weeks from the retro-orbital plexus using the capillary pipette method of Halpern and Pacaud, (1951), centrifuged at 1800 r.p.m. and stored in $-20{ }^{\circ} \mathrm{C}$. Creatinine level is determined according to the method of enzymatic creatinine essay (Heinegård $D$ and Tiderström G, 1973).

\section{Histopathological study:}

Kidney samples, obtained at the end of the experiment (the $12^{\text {th }}$ week), were fixed in $10 \%$ formalin and processed for paraffin blocks. Sections of 4-5 microns were cut and stained by hematoxylin\& eosin according to Bancroft \& Stevens, (1977) and examined by light microscope. The sections were viewed and photographed on an Olympus light microscope with attached photograph machine.

\section{STATISTICAL ANALYSIS:}

Data obtained from the biochemical analysis are represented in tables as Mean \pm Standard deviation (mean $\pm \mathrm{SD})$. The One-Way ANOVA test was used for statistical analysis of data. The analysis was done using the SPSS-PC computer software package version 10 Abacus Concepts (1989).

\section{RESULTS}

No difference was observed between the negative and positive control groups concerning the Creatinine levels.

At the end of the fourth week, the creatinine level of the Methotrexatetreated group (group 4) increased about 4.77 times than that of the negative control group $(\mathrm{P}<0.000)$. With the use of the $\mathrm{N}$-acetylcysteine (group 5), the creatinine level decreased significantly about $22.1 \%$ as compared to that of the Methotrexate-treated group, but still 3.7 times higher than that of the negative control group $(\mathrm{P}<0.000)$. With the use of the Melatonin (group 6), the creatinine level was insignificantly decreased as compared to that of the Methotrexate-treated group, but still $27.4 \%$ higher than that of the MTX- N-acetylcysteine treated group. It was about 4.7 times higher than that of the negative control group $(\mathrm{P}<0.000)$.At the end of the eighth week, the creatinine level of the Methotrexate-treated group (group 4) increased about 5.2 times than that of 
the negative control group $(\mathrm{P}<0.000)$. With the use of the $\mathrm{N}$-acetylcysteine (group 5), the creatinine level decreased significantly about $32.6 \%$ as compared to that of the Methotrexatetreated group, but still it was about 3.5 times higher than that of the negative control group $(\mathrm{P}<0.000)$. With the use of the Melatonin (group 6), the creatinine level was insignificantly decreased as compared to that of the Methotrexate-treated group (group 4), but still it was about $30.9 \%$ higher than that of the MTX- N-acetylcysteine treated group (group 5). It was about 4.6 times higher than that of the negative control group $(\mathrm{P}<0.000)$. At the end of twelve weeks, the creatinine level of the Methotrexate-treated group (group 4) increased about 6 times than that of the negative control group $(\mathrm{P}<$ $0.000)$. With the use of the Nacetylcysteine(group 5), the creatinine level decreased significantly about $42.6 \%$ as compared to that of the Methotrexate-treated group(group 4), but still 3.47 times higher than that of the negative control group $(\mathrm{P}<0.000)$. With the use of the Melatonin (group 6), the creatinine level was insignificantly decreased as compared to that of the Methotrexate-treated group(group 4), but still $65 \%$ higher than that of the MTX- N-acetylcysteine treated group (group 5). It was about 4.8 times higher than that of the negative control group $(\mathrm{P}<0.000)$ (Table 1).

The renal cortex of the control group showed numerous renal corpuscles and convoluted tubules of the renal cortex. Each renal corpuscle appeared as a dense, rounded structure formed of glomerulus surrounded by a narrow capsular (urinary) space, followed by a single row of flat squamous cells of the parietal layer of Bowman's capsule (Figure 1).

The renal cortex of the Methotrexate-treated group (group 4) showed cytoplasmic vacuolation and pyknosis of the nuclei of theproximal convoluted tubules (PCT). In addition the tubular epithelium exhibited exfoliation with intraluminal cast formation. Multiple glomeruli were atrophic with widening of the urinary spaces. The peritubular capillaries were congested (Figure 2\&3). Improvement of the histological appearance was observed in the renal cortex of the NAC-treated group (group 5). The glomeruli were nearly normal with a slight widening of the urinary spaces. Some pathological findings were found in the renal tubular epithelium in the form of pyknosis of the nuclei, exfoliation, cytoplasmic vacuolation with tubular cast formation (Figure 4).

More deterioration of the renal cortex was observed in the melatonintreated group (group 6). Severe congestion of the glomeruli and of the peritubular capillaries was observed, which led finally to massive vascular extravasation. The tubular epithelium showed pyknosis and apoptosis of the nuclei of the PCT. In addition, cytoplasmic vacuolation, exfoliation with the tubular cast formation were constant findings in the tubules of this group (Figure 5). 
Table (1): Shows ANOVA one-way statistical analysis of the creatinine levels (ng/ dl) in all studied groups throughout the experimental period in rats.

\begin{tabular}{|c|c|c|c|}
\hline \multirow{2}{*}{ Groups } & \multicolumn{3}{|c|}{ Creatinine levels (ng/ dl)(mean \pm SD) } \\
\cline { 2 - 4 } & $\mathbf{4}^{\text {th }}$ week & $\mathbf{8}^{\text {th }}$ week & 12 $^{\text {th }}$ week \\
\hline Group 1 & $0.53 \pm 0.15^{*}$ def & $0.52 \pm 0.17^{*}$ def & $0.48 \pm 0.16^{*}$ def \\
\hline Group 2 & $0.45 \pm 0.14^{*}$ def & $0.41 \pm 0.18^{*}$ def & $0.41 \pm 0.18^{*}$ def \\
\hline Group 3 & $0.42 \pm 0.17^{*}$ def & $0.46 \pm 0.15^{*}$ def & $0.45 \pm 0.15^{*}$ def \\
\hline Group 4 & $2.53 \pm 0.34^{*}$ abcef & $2.731 \pm 0.28^{*}$ abcef & $2.91 \pm 0.26^{*}$ abcef \\
\hline Group 5 & $1.97 \pm 0.08^{*}$ abcdf & $1.84 \pm 0.10^{*}$ abcdf & $1.67 \pm 0.17^{*}$ abcdf \\
\hline Group 6 & $2.51 \pm 0.20^{*}$ abcde & $2.41 \pm 0.19^{*}$ abcde & $2.32 \pm 0.18^{*}$ abcde \\
\hline
\end{tabular}

$*=$ statistical significant difference at $\mathrm{p} \leq 0.05$

$\mathbf{a}=$ significant difference versus group $1 \quad \mathbf{b}=$ significant difference versus group 2

$\mathbf{c}=$ significant difference versus group $3 \quad \mathbf{d}=$ significant difference versus group 4

$\mathbf{e}=$ significant difference versus group $5 \quad \mathbf{f}=$ significant difference versus group 6

Group 1= Negative control.

Group 2= Rats received doses equal to $1 / 14$ of $\mathrm{LD}_{50}$ of $\mathrm{N}$-acetylcysteine.

Group 3= Rats received doses equal to $1 / 36$ of $\mathrm{LD}_{50}$ of melatonin.

Group 4= Rats received doses equal to $1 / 7$ of $\mathrm{LD}_{50}$ of methotrexate.

Group 5= Rats received doses equal to $1 / 7$ of $\mathrm{LD}_{50}$ of methotrexate $\& 1 / 14$ of $\mathrm{LD}_{50}$ of N-acetylcysteine.

Group 6= Rats received doses equal to $1 / 7$ of $\mathrm{LD}_{50}$ of methotrexate \& $1 / 36$ of $\mathrm{LD}_{50}$ of melatonin.

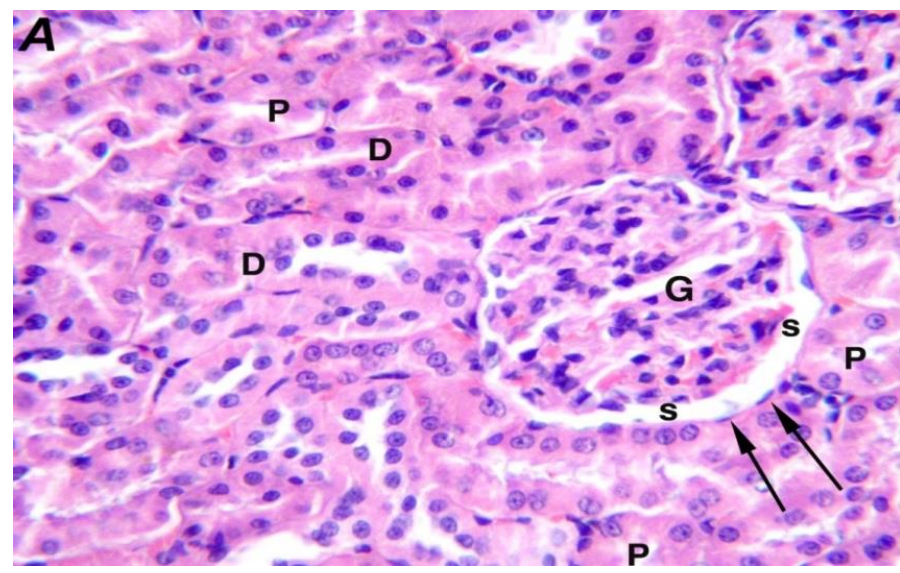

Figure (1): Photomicrograph of a cross section in the renal cortex of a rat of the negative control group (group 1) showing a normal glomerulus (G), parietal layer of Bowman's capsule (arrows) and urinary spaces. Note normal PCT (P) and DCT (D) (H \& E; 400x). 


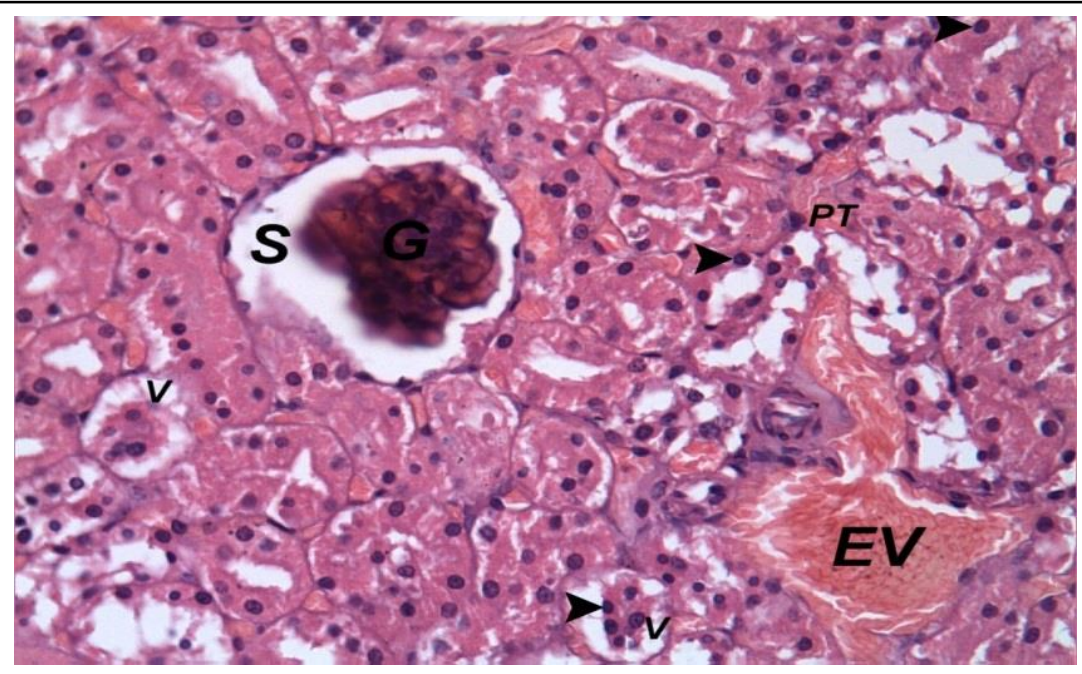

Figure (2): Photomicrograph of a cross section in the renal cortex of a rat of the Methotrexate-treated group (group 4) showing pyknosis of the nuclei of the PCT (arrowheads) of the tubular epithelium. Both the glomeruli $(\mathrm{G})$ and the peritubular capillaries (PC) are congested. Widening of the urinary spaces (S) and massive extravasation of the blood $(\mathrm{EV})$ have been observed. (H\&E $\mathrm{x}$ 400)

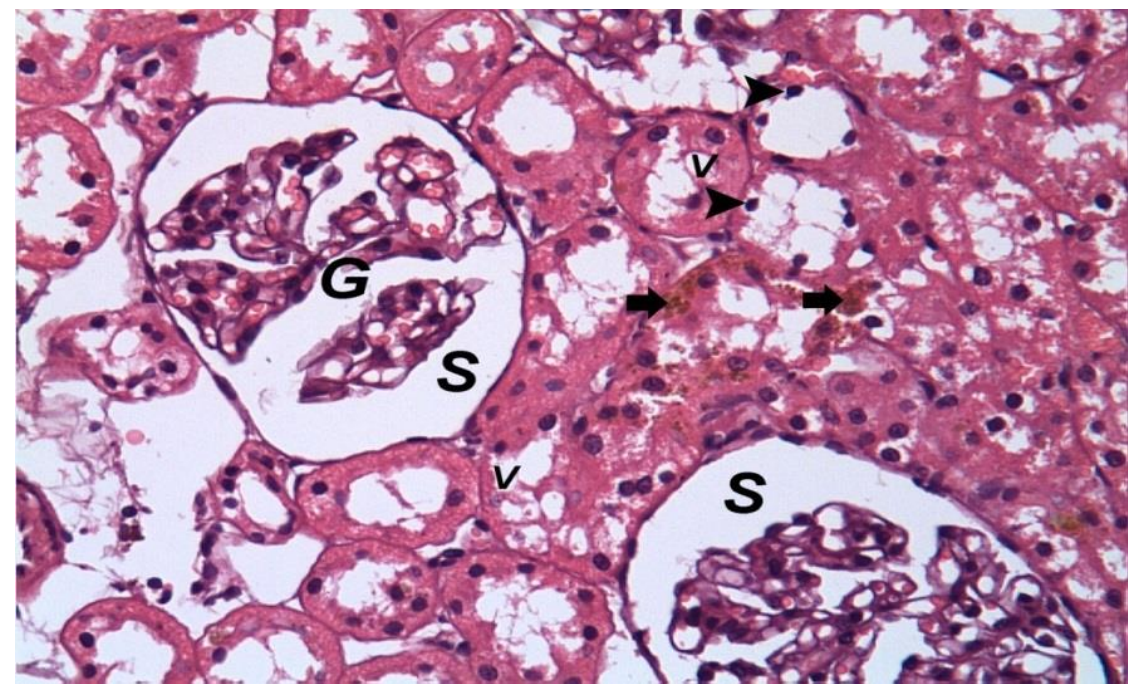

Figure (3): Photomicrograph of a cross section in the renal cortex of a rat of the Methotrexate-treated group (group 4) showing pyknosis of the nuclei of the PCT (arrowheads) with cytoplasmic vacuolation (V) of the tubular epithelium. The glomeruli $(\mathrm{G})$ are atrophic with widening of the urinary spaces $(\mathrm{S})$. (H\&E x 400) 


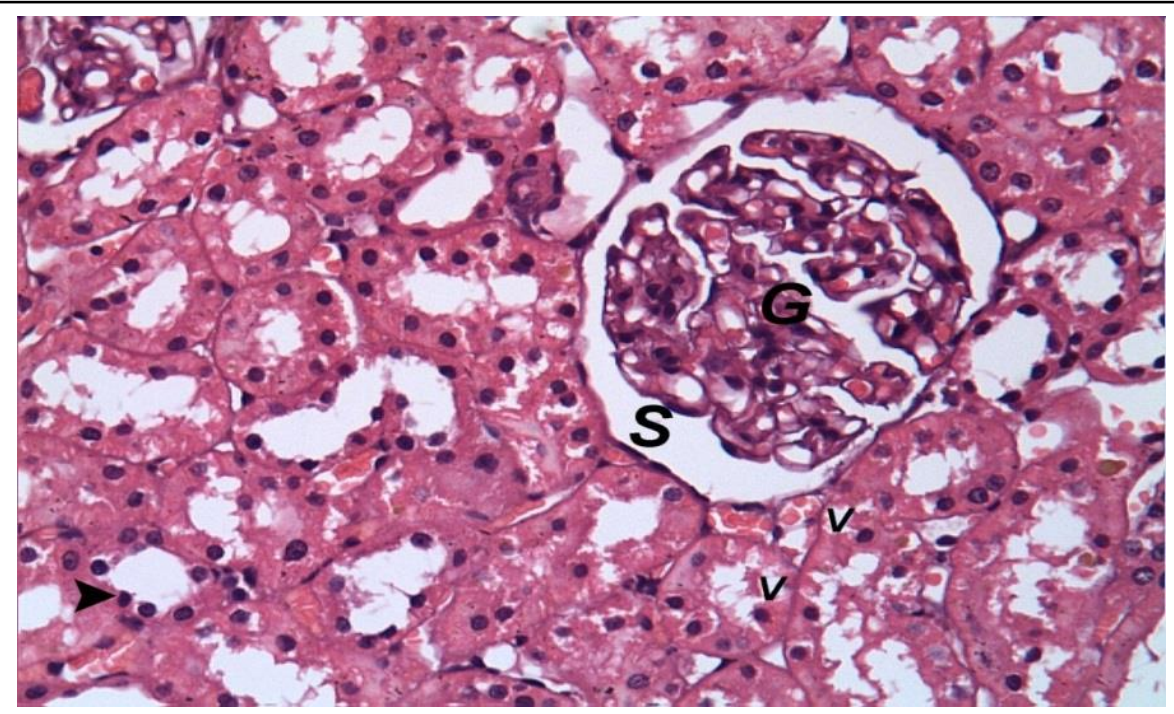

Figure (4): Photomicrograph of a cross section in the renal cortex of a rat of the MTX- N-acetylcysteine treated group (group 5) showing pyknosis of the nuclei of the renal tubules (arrowhead) with vacuolation (V) of the tubular epithelium. The glomeruli (G) are slightly congested and the urinary spaces (S) are normal. (H\&E x 400)

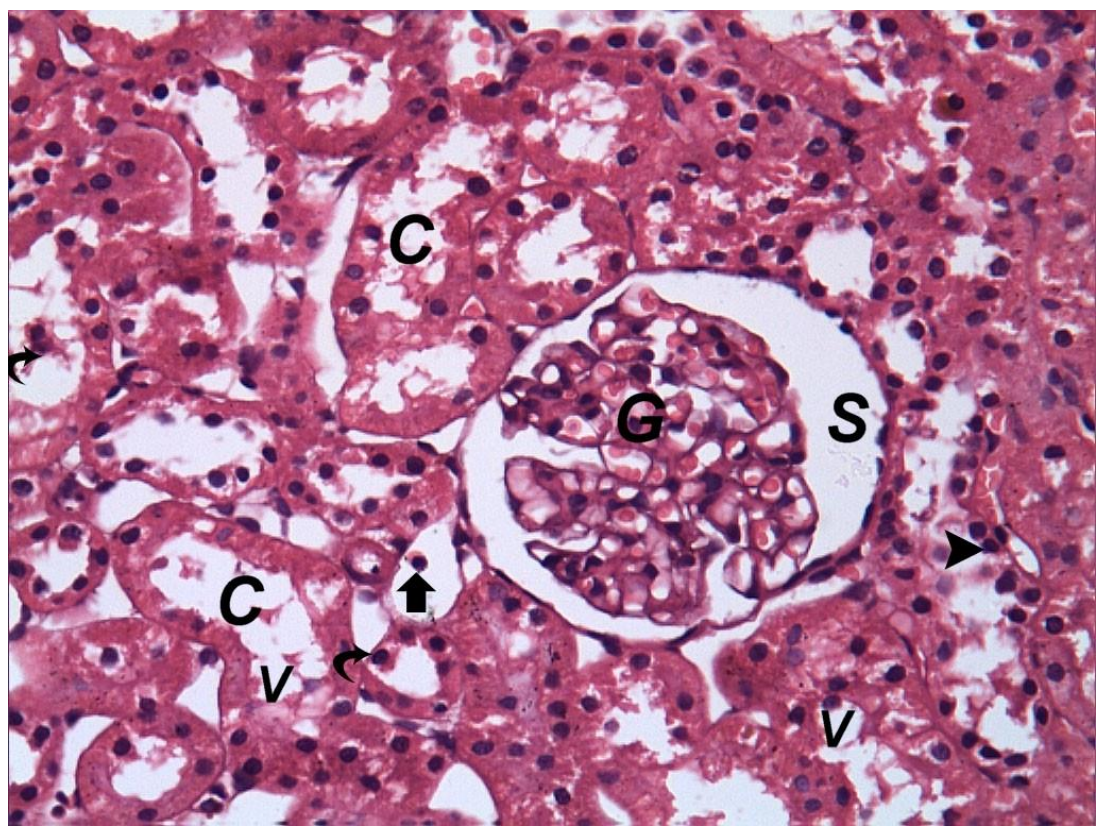

Figure (5): Photomicrograph of a cross section in the renal cortex of a rat of the MTX-Melatonin treated group (group 6) showing pyknosis of the nuclei of the PCT (arrowhead). Cytoplasmic vacuolation (V) and exfoliation (curved arrows) of the tubular epithelium have been observed. Apoptosis of the tubular nuclei (arrow) with cast formation have been identified. The glomeruli $(\mathrm{G})$ are congested and atrophic with widening of the urinary spaces $(\mathrm{S})(\mathrm{H} \& \mathrm{E}$ $\mathrm{x}$ 400) 


\section{DISCUSSION}

The purpose of this study was to test the protective effect of $\mathrm{N}$-acetyl cysteine and Melatonin on Methotrexate induced renal toxicity in albino rats.

The current study revealed significant elevation in serum creatinine concentrations of the methotrexate-treated group (group 4) throughout the study compared with the negative control group. It increased about 4.77, 5.2 and 6 times than that of the negative control group at the $4^{\text {th }}, 8^{\text {th }}$ and $12^{\text {th }}$ weeks respectively $(\mathrm{P}<0.000)$. An elevated serum creatinine signifies kidney injury (Ponte et al., 2008).In accordance with these results, many authors reported that MTX administration increases plasma BUN and creatinine levels significantly (Kolli et al., 2009 and Kintzel, 2001).Kintzel, 2001added that administration of MTX in high doses can cause acute renal failure. On the other hand, these results were in disagreement with those of Cetiner et al.,2005 who reported that MTX administration does not elevate BUN and creatinine significantly.

This biochemical dysfunction in the methotrexate-treated group (group 4) was in harmony with the morphological abnormalities of the examined renal sections that revealed maximal affection of the renal cortex of rats that received MTX only (group 4) in the form of a condensation of chromatin (pyknosis) of the nuclei of the proximal convoluted tubules (PCT) which reflected an irreversible cell injury (Kroemer et al., 2009), apoptosis has been also observed in the kidney of the MTX-treated group. Apoptosis may be induced by reactive oxygen species (ROS) (Buttke and Sandstrom, 1994).Additionally, exfoliation of the lining epithelial cells of renal tubules was detected which could be the result of ischemia induced by the oxygen derived free radicals (Edelstein et al., 1997) or induced by the affection of the rennin-angiotensin mechanism (Humes et al., 1997).Edelstein et al., 1997 added that this ischemia causes functional and structural alteration of the lining epithelial cells leading to their detachment.

Intraluminal cast formation of the renal tubules was also noticed in the methotrexate-treated group (group 4) following the intraluminal exfoliation of the lining epithelial cells. Goligorsky and his co-workers declared that the necrotic epithelial cells provided a matrix for intraluminal cast formation (Goligorsky et al., 1993).Furthermore, the renal tubules of the methotrexatetreated group (group 4) showed the presence of cytoplasmic vacuolization of the lining epithelial cells which might be due to the disturbance of the sodium pump, as a sequence of impaired oxidative phosphorylation, which results in hydropicdegeneration (Therien and Blostein, 2000).

The current study revealed that the most sensitive part of the kidney to the toxic effects of MTX was the epithelium of the PCT. This could be explained by the wide distribution of the enzymes needed for the uptake of MTX such as the apical gammaglutamyltranspeptidase, glucose-6 phosphatase, alkaline phosphatase, ATPase and succinic dehydrogenase in the cells of the PCT (Diamond and Zalups, 1998).

$\mathrm{N}$-acetylcysteine, derived from the simple amino acid cysteine, provides significant protection against a broad array of modern toxins. These include acrolein (found in cigarette smoke and 
auto exhaust), paraquat (a toxic herbicide), and the side effects of cyclophosphamide, adriamycin (both anticancer drugs) and halothane (an anesthetic) (Boman et al., 1983).

In the present work, benificial effect on creatinine levels was recorded on supplementation of $\mathrm{N}$-acetylcysteine concomitantly with methotrexate in group 5; it reduced creatinine levels significantly when compared to the non-supplemented group 4 that was treated with $\operatorname{MTX}(\mathrm{P}<0.000)$ in all intervals.

Tepel et al., 2000 demonstrated that administration of NAC reduced contrast media nephrotoxicity. This demonstration was based on a milder elevation of serum creatinine following administration of contrast medium when associated with NAC. The morphological changes and histopathologic findings of the kidney sections were significantly milder when NAC was co-administered with MTX in groups 5 as compared to the effects of MTX when used alone in group 4 . Agrawal et al., 2008 concluded that it might be useful to use NAC to minimize MTX-induced nephrotoxicity as evidenced by the improvement of the glomerular and the peritubular capillaries congestion (Agrawal et al., 2008).

On the other hand, the use of the melatonin in combination with methotrexate in group 6 produced minimal non-significant reduction of the creatinine level relative to group 4 at the $4^{\text {th }}, 8^{\text {th }}$ and $12^{\text {th }}$ weeks ( $\left.P>0.05\right)$. This observed chemical effect in group 6 was supported by the deterioration of the renal cortical structure as observed in the melatonin and MTX group (group 6). These results were inconsistent with those of Kilic et al., (2013) who reported that both serum creatinine and urea nitrogen increased significantly following cisplatin administration alone and these values decreased significantly with melatonin co-treatment of cisplatin-treated rats. This discrepancy observed in the protective effect of melatonin on the kidney could be attributed to the difference in the experimental protocol as Kilic et al., (2013) administered melatonin two days before the single intraperitoneal injection of cisplatin.

In conclusion, in the present work, benificial effect on creatinine levels was recorded on supplementation of $\mathrm{N}$ acetylcysteine concomitantly with methotrexate in group 5; it reduced creatinine levels significantly when compared to the non-supplemented group 4 that was treated with MTX $(\mathrm{P}<$ $0.000)$ in all intervals.

In the view of the present study, we recommend to conduct the same study on human beings in order to investigate the feasibility and suitability of the results of the present study on human beings.

\section{REFERENCES}

Abacus Concepts (1989): Super ANOVA. Abacus Concepts Inc, Berkeley, CA.

Agrawal, V., Vinod, P. B., Krishnani, N., and Sharma, R. K. (2008): A case of collapsing glomerulopathy associated with febrile illness. Indian J Pathol Microbiol, 51(4): 509-11.

Bancroft, J.D.and Stevens, A. ( 1977 ):Theory and practice of histological techniquesChurchill Livingstone, New York, USA.

Boman G, Backer U, Larsson S, Melander B, and Wahlander $\mathrm{L}$. (1983): Oral acetylcysteine reduces exacerbation rate in chronic bronchitis: a report of a 
trial organized by the Swedish Society for Pulmonary Diseases. Eur J Respir Dis. Aug; 64(6):40515.

BuchenS,Ngampolo D, Melton RG, et al. (2005):Carboxypeptidase G2 rescue in patients with methotrexate intoxication and renal failure. Br J Cancer ;92:4807.

Buttke, T. M. and Sandstrom, P. A. (1994): Oxidative stress as a mediator of apoptosis. Immunol Today, 15(1): 7-10.

Cetiner, M., Sener, G., Sehirli, A. O., Ekşioğlu-Demiralp, E., Ercan, F., Sirvanci, S., Gedik, N., Akpulat, S., Tecimer, T., and Yeğen, B. C. (2005): ToxicolApplPharmacol. 15;209(1):39-50.

Diamond, G. L. and Zalups, R. K. (1998): Understanding renal toxicity of heavy metals. Toxicol Pathol, 26(1): 92-103.

Duong MH, MacKenzie TA, and Malenka DJ (2005): Nacetylcysteine prophylaxis significantly reduces the risk of radiocontrast-induced

nephropathy: comprehensive meta-analysis. Catheter CardiovascInterv.; 64:471-9.

Edelstein, C. L., Ling, H., and Schrier, R. W. (1997): The nature of renal cell injury. Kidney Int, 51(5): 1341-51.

Goligorsky, M. S., Lieberthal, W., Racusen, L., and Simon, E. E. (1993): Integrin receptors in renal tubular epithelium: new insights into pathophysiology of acute renal failure. Am J Physiol, 264(1 Pt 2): F1-8.

Halpern,

B.N, anPacaud,A.(1951):C.R.Soc.Biol .,Paris.145, 1465.
Heinegård D, and Tiderström G. (1973): Determination of serum creatinine by a direct colorimetric method. Clin. Chim.Acta. 43:305310.

Humes, H. D., MacKay, S. M., Funke, A. J., and Buffington, D. A. (1997): Acute renal failure: growth factors, cell therapy, and gene therapy. Proc Assoc Am Physicians, 109(6): 547-57.

Kilic et al.(2013): Nutrition \& Metabolism, 10:7 http://www.nutritionandmetabolis m.com/content/10/1/7 Retrieved 25 January 2015.

Kintzel, P. E. (2001): Anticancer druginduced kidney disorders. Drug Saf, 24(1): 19-38.

Koch AC, Block KI, Mead MN, Tothy PK, Newman RA, and Gyllenhaal C (2009): Impact of antioxidant supplementation on chemotherapeutic toxicity: a systematic review of the evidence from randomized controlled trials. Int. J. Cancer 123 (6): 1227-39.

Kolli, V. K., Abraham, P., Isaac, B., and Selvakumar, D. (2009): Neutrophil infiltration and oxidative stress may play a critical role in methotrexateinduced renal damage. Chemotherapy, 55(2): 83-90.

Kroemer, G., Galluzzi, L., Vandenabeele, P. (2009): Classification of cell death: recommendations of the Nomenclature Committee on Cell Death 2009. Cell Death Differ, 16(1): 3-11.

Pannu N, Manns B, Lee $\mathrm{H}$, and Tonelli M (2004): Systematic review of the impact of $\mathrm{N}$ acetylcysteine on contrast nephropathy. Kidney Int.; 65:1366-74. 
Ponte, B., Felipe, C., Muriel, A., Tenorio, M. T., and Liaño, F. (2008): Long-term functional evolution after an acute kidney injury: a 10-year study. Nephrol Dial Transplant, 23(12): 3859-66.

Rodriguez, C., J.C. Mayo, R.M. Sainz, I. Antolín, F. Herrera, V. Martín and R.J. Reiter (2004): Regulation of antioxidant enzymes: a significant role for melatonin. J Pineal Res 36, 1-9.

Tepel M, and Zidek W (2004): NAcetylcysteine in nephrology; contrast nephropathy and beyond. CurrOpinNephrolHypertens.; 13:649-54.

Tepel M, van der Giet M, Schwarzfeld C, Laufer U, Liermann D, and Zidek W (2000): Prevention of radiographic-contrast-agent-induc ed reductions in renal function by acetylcysteine. $\mathrm{N}$ Engl $\mathrm{J}$ Med; 343: $180-184$.

Therien, A. G. and Blostein, R. (2000): Mechanisms of sodium pump regulation. Am J Physiol Cell Physiol, 279(3): C541-66.

Widemann BC, Adamson PC (2006): Understanding and managing methotrexate nephrotoxicity. The Oncologist ;11:694-703.

Widemann BC, Balis FM, KempfBielack B, et al.(2004): Highdose methotrexate-induced nephrotoxicity in patients with osteosarcoma. Cancer ; 100:22222232. 


\section{الملخص العربي}

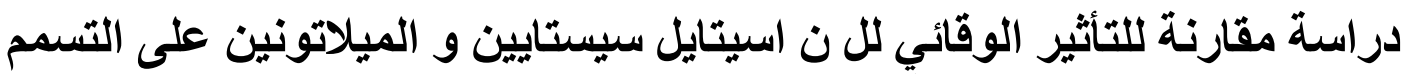

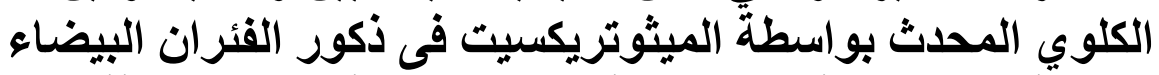

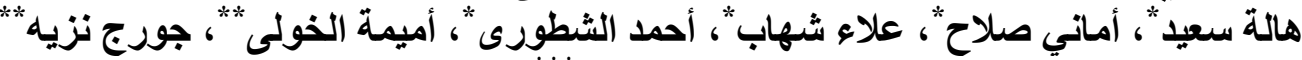

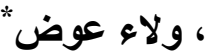

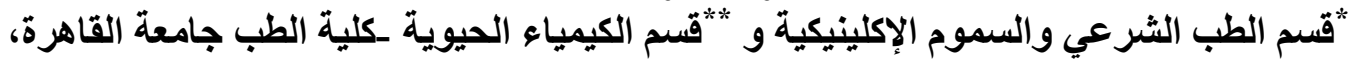

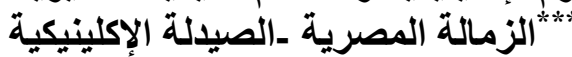

يستخدم عقار الميثوتريكسيت على نطاق واسع في علاج الأورام الخبيثة وكثير من الأمراض الالتهابية وارتبط العلاج بالميثوتريكسيت بالتسمم الكلوي. وتهدف هذه الاراسة الى مقارنة الأثر الوقائي لعقار ن اسيتايل سيستايين وعقار الميلاتونين على التسمم

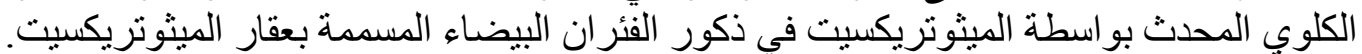

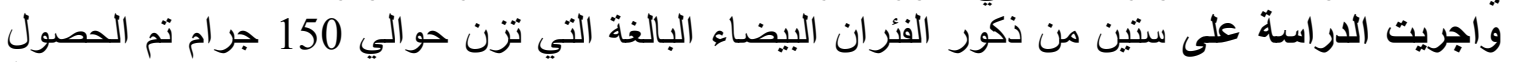

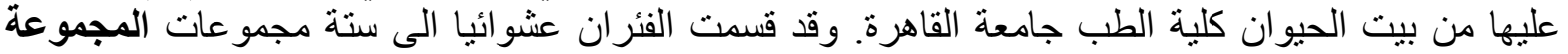

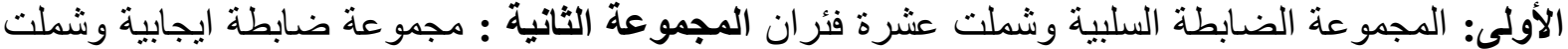

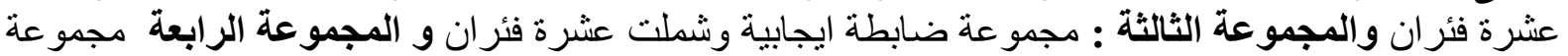

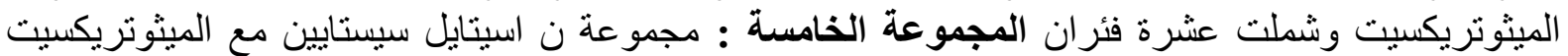

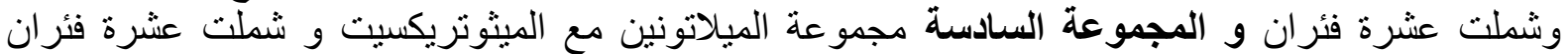
وتمت إعاشتهم في أقفاص معدنية في حجرة نظيفة جيدة التهوية وتغذيتهر على الغذاء المعملي المناسب التئ و السماح

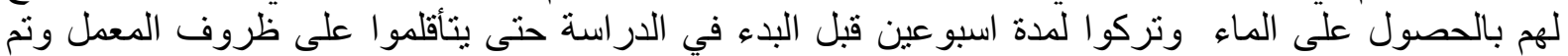

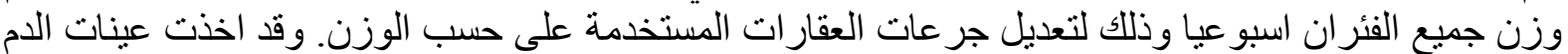

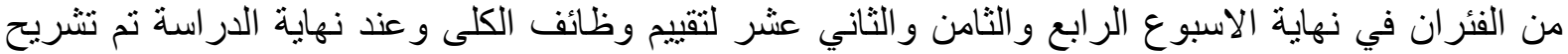

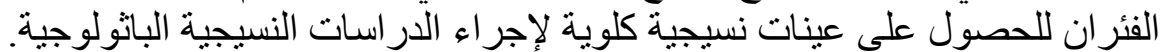

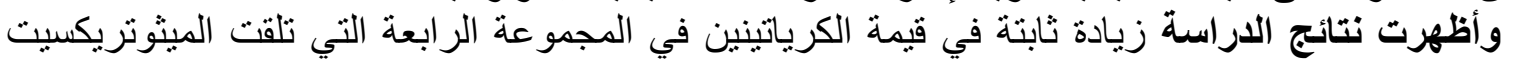

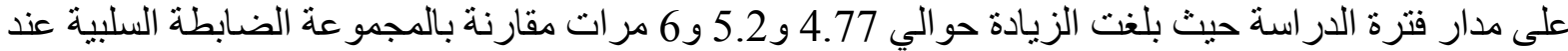

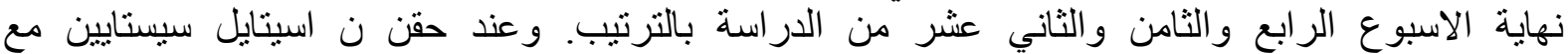

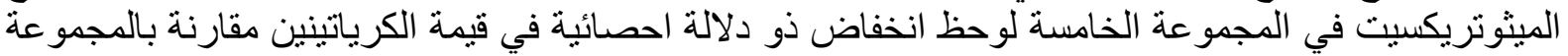

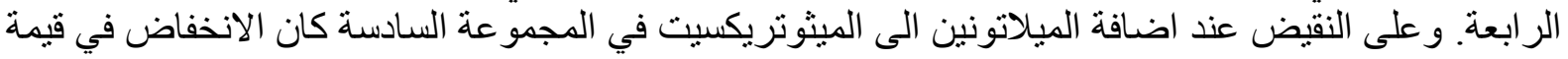

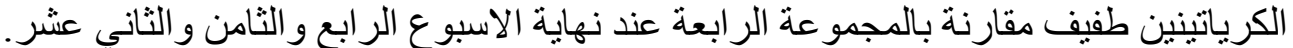
وأكدت نتائج الفحص الههتولوجي (الميكروسكوبي) للكلى على النتائج الكيميائية السابقة حيث الظهرئ الظهرت

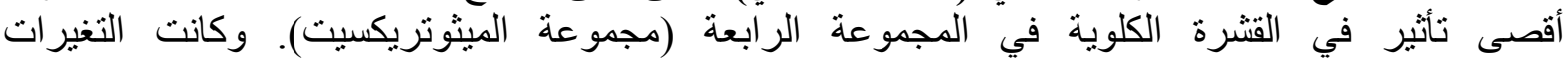

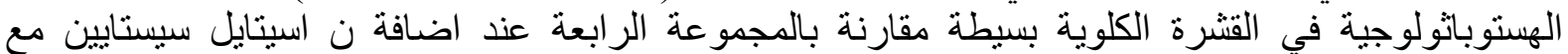
الميثوتريكسيت في المجموعة الخامسة وفى المقابل لوحظ عدم تحسن القشرة الكلوية في المجموعة السادسة مقارنة بالمجمو عة الر ابعة.

وخلصت الدراسة الى ان تعاطيى ن اسيتايل سيستايين بالتز امن مع الميثوتريكسيت قد ادى الى تحسن الحس ملحوظ

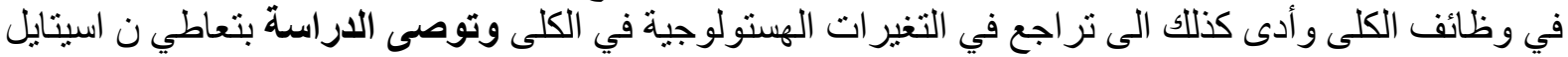

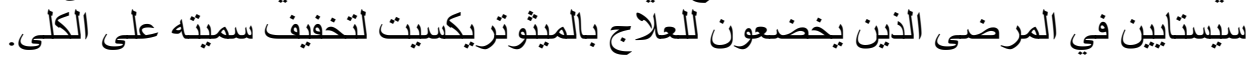

